Kotyrlo, T.V. Pedagogization of parents and family members as an actuality of adult education. Osvita doroslykh: teoriia, dosvid, perspektyvy. Kyiv [in Ukrainian].

Novyk, I. M. \& Tkachenko, K. O. (2017). Pedagogical education of parents. Molodyj vchenyj. 12 (52). 417-420 [in Ukrainian].

Paskevska, Yu.A., Shcherbyna, D.V. (2019). Pedagogical principles of parental education in secondary and out-of-school institutions. Kyiv: IPOOD Imeni Ivana Ziaziuna NAPN Ukrainy [in Ukrainian].

Postovyi, V. H. (1994). The modern family and its pedagogy. Kyiv: Osvita. 284. [in Ukrainian].

Savchenko, M. S. (2012). Peculiarities of joint activities of a family and a preschool educational institution on gender issues. Proceedings of the ninth international scientific-practical Internet conference "Society. Science. Culture». URL: http://surl.li/inqq [in Ukrainian].

Strunnikova, D.I. (2001) Family upbringing as one of the conditions for the socialization of a child's personality. Collection of scientific works of the G.S. Kostyuk Institute of Psychology of the Academy of Pedagogical Sciences of Ukraine «Problems of general and pedagogical psychology», 3, 4. [in Ukrainian].

Taranova, Ye. A. т (Ed.) (1986). Kindergarten education and training program. Kyiv: Radianska shkola. [in Ukrainian].

УДК [378.091.212.064.3]:316.722(477)

DOI: https://doi.org/10.35387/od.2(18).2020.86-97

Кірсанова Світлана Станіславівна - асистент кафедри іноземних мов Мелітопольського державного педагогічного університету імені Богдана Хмельницького

ORCID ID: https://orcid.org/0000-0001-9427-3189

E-mail: karrissiamercado77@gmail.com

\title{
ПЕДАГОГІЧНІ УМОВИ ФОРМУВАННЯ ГОТОВНОСТІ СТУДЕНТСЬКОї МОЛОДІ ДО МІЖОСОБИСТІСНОЇ ВЗАЄМОДІї У ПОЛІКУЛЬТУРНОМУ ВИМІРІ ПЕДАГОГІЧНОЇ ОСВІТИ
}

Анотація. В оглядовій статті обгрунтовано педагогічні умови формування готовності міжособистісної взаємодії студентської молоді в умовах полікультурного середовища педагогічного університету як сукупність зовнішніх і внутрішніх фракторів освітнього процесу, від реалізації яких залежить рівень сформованості готовності здобувачів вищої освіти до означеного процесу. Розвиток українського полікультурного соціуму пов'язаний із етнонаціональною політикою України. Полікультурна освіта в сучасних соціокультурних умовах претендує на статус нової освітньої парадигми, яка передбачає реалізацію моделі освітнього процесу в закладі вищої освіти з урахуванням багатокультурності (етнічної, релігійної, мовної, соціальної тощо).

мета статmі полягає в обгрунтуванні педагогічних умов 
формування готовності міжособистісної взаємодії студентської молоді в полікультурному середовищі педагогічного університету. Першою умовою автором визначено організацію освітнього процесу з урахуванням досвіду та цінностей студентів. Друга умова, гуманітаризація освітнього процесу, спрямована на фрормування міжособистісної взаємодії студентської молоді в полікультурному середовищі педагогічного університету. Гуманітарні знання $є$ основою виховання гуманістичних переконань, які знайдуть їхню реалізацію у майбутній педагогічній практиці. Третьою умовою формування міжособистісної взаємодії студентської молоді в полікультурному середовищі педагогічного університету $є$ гуманістична взаємодія викладачів педагогічного університету. Процес формування міжособистісної взаємодії студентської молоді в полікультурному середовищі педагогічного університету слід вибудовувати з використанням міжпредметних зв'язків суміжних курсів. Результати наукового пошуку дали можливість стверджувати значущість i результативність обгрунтованих педагогічних умов.

Ключові слова: міжособистісна взаємодія, педагогічні умови, полікультурне середовище, освітній процес, заклад вищої освіти.

Kirsanova Svitlana - Assistant of the Foreign Languages Department Melitopol State Pedagogical University named after Bohdan Khmelnytsky.

ORCID ID: https://orcid.org/0000-0001-9427-3189

E-mail: karrissiamercado77@gmail.com

\title{
PEDAGOGICAL CONDITIONS OF STUDENT YOUTH READYNESS FORMATION TO INTERPERSONAL INTERACTION IN PEDAGOGICAL EDUCATION POLYCULTURAL DIMENTION
}

\begin{abstract}
The article deals with the substantiation of pedagogical conditions with student youth readiness formation of interpersonal interaction in a multicultural environment of the pedagogical University, the set of external and internal factors of the educational process, the implementation of which the level of higher education applicants' readiness to the specified process depends on.

It is difficult to solve compound and complex tasks of global and European integration of the Ukrainian state without the appropriate public transformations that will guarantee the society dynamic development. But it is necessary to ensure its integrity, preservation of identity, the reproduction and the development of culture, the restoration and the elevation of valuable orientations, the definition of specific ideological guidelines, a significant change of the state political model of governing and public administration processes, that is, a comprehensive modernization of the state, its reorientation to a new, innovative way of development.
\end{abstract}

The purpose of the study is to substantiate the pedagogical conditions of 
the student's youth readiness formation of interpersonal interaction in the multicultural environment of the pedagogical university. The first condition the author defines is the organization of the educational process taking into account the of students' experience and values. The second condition, the humanization of the educational process, is aimed at formation of student youth interpersonal interaction in a multicultural environment of the pedagogical university. Humanities knowledge are the basis for humanistic beliefs education of that will find their implementation in a future pedagogical practice. The third condition for the formation of interpersonal student interaction in the multicultural environment of the Pedagogical University is a humanistic interaction of pedagogical university teachers. The process of student youth interpersonal interaction formation in a multicultural environment of a pedagogical university should be built with the usage of related courses interdisciplinary links.

The results of the scientific research made it possible to assert about the significance of reasonable pedagogical conditions.

Key words: interpersonal interaction, pedagogical conditions, multicultural environment, educational process, institution of higher education.

Постановка проблеми, її актуальність. Складні та комплексні завдання глобальної та європейської інтеграції української держави важко вирішити без відповідних суспільних трансформацій, які стануть гарантією динамічного розвитку суспільства. Але при цьому необхідно забезпечити його цілісність, збереження ідентичності, відтворення та розвиток культури, відновлення та піднесення ціннісних орієнтацій, визначення конкретних ідеологічних настанов, істотну зміну політичної моделі управління державою та керування суспільними процесами тощо - тобто всебічну модернізацію держави, іï переорієнтацію на новий, інноваційний шлях розвитку (Бондаренко, 2011).

У міжнародному просторі важливу роль відіграють інтеграційні процеси. Інтеграційні процеси ґрунтуються на міжсистемній взаємодії суспільно-політичної, соціально-економічної, науково-технологічної, соціокультурної сфрер суспільного життя, які, з одного боку, покликані забезпечити національне самозбереження, а з іншого, з огляду на зовнішню залежність, мають схильність до саморуйнування. При цьому міжсистемна взаємодія розглядається у двох площинах: внутрішній, зовнішній. Внутрішня міжсистемна взаємодія визначає спроможність держави до нових міждержавних утворень і формується на основі взаємодії основних рівнів суспільного розвитку - свідомісного, політичного, економічного, соціального $\mathrm{i}$ культурного. Єдність і стабільність такої взаємодії забезпечує державі спроможність до самоорганізації, адаптації до умов зовнішнього середовища, активне включення у міжнародні процеси, зберігаючи при цьому національну самобутність. В іншому разі інтеграційні процеси призведуть до поглинання держави та відкинуть її на периферію глобалізаційного простору (Бондаренко, 2011). 
У таких умовах значущість закладу вищої освіти й педагогічної науки $€$ незаперечною, оскільки вони стають гарантами забезпечення громадського миру, збереження культури та моральності суспільства, а фрормування міжособистісної взаємодії студентської молоді в умовах полікультурного середовища педагогічного університету - дієвим концептом цього процесу.

Аналіз останніх досліджень і публікацій. Обґрунтування терміна «міжособистісна взаємодія» і значний внесок у його розробку належить таким вченим, як Б. Ананьєв (2001), О. Бодальов (1993), Б. Ломов (2002) та ін. Процес формування міжособистісної взаємодії був предметом досліджень українських учених - педагогів та психологів протягом останніх двох десятиліть, а саме: Л. Бронської (підготовка майбутніх учителів до взаємодії у виховній діяльності) (Бронська, 2000), Н. Будій (застосування прийому міжособистісної взаємодії у наративних технологіях) (Будій, 2008), І. Булах (психологічні аспекти міжособистісної взаємодії викладача й студентів) (Булах, 2005), В. Васютинського (дослідження можливостей міжособистісної взаємодії у груповій феноменології) (Васютинський, 2010) та ін.

В останні роки тему міжособистісної взаємодії студентської молоді та іiі вдосконалення висвітлено у значній кількості наукових праць (О. Батуріна, О. Горчакова, О. Грива С. Духновський А. Канаматова, В. Коваль, О. Кузнецова, П. Кендзьор, О. Колюх, Д. Порох, С. Смагіна, А. Федяєва та ін.).

Мета публікації полягає в обґрунтуванні педагогічних умов формування готовності міжособистісної взаємодії студентської молоді в полікультурному середовищі педагогічного університету.

Виклад основного матеріалу дослідження. На сучасному етапі соціально-економічного, політичного, духовного розвитку суспільства індивід має вибудовувати міжособистісні стосунки з абсолютно різними людьми та взаємодіяти 3 ними для досягнення успіху. 3 метою забезпечення ефективності взаємодії сучасна людина повинна володіти певними комунікативними, організаторськими та іншими якостями, навичками спілкування тощо.

Пошуки визначення поняття «педагогічні умови» показали, що цю категорію досліджували й обґрунтовували науковці О.Гура, Н. Житнік, М. Звєрєва, В. Стасюк та ін. Умови як змістову характеристику компонентів педагогічної системи (зміст, методи, фрорми, засоби, особливості взаємодії учасників педагогічного процесу тощо) розглядає М. Звєрєва (Зверєва, 1987).

Від способу впливу на освітній процес, педагогічні умови підрозділяються на зовнішні та внутрішні (Жернов, 1999). На думку В. Жернова, зовнішні умови $є$ продуктом функціонування політичної, соціально-економічної, освітньої та інших систем зовнішнього середовища й реалізуються через відповідні фрактори. Автор доводить, що внутрішні педагогічні умови $€$ похідними завданнями відповідного педагогічного процесу та являють собою сукупність педагогічних заходів, що забезпечують 
ефективне розв'язання цих завдань.

Зазначимо, що у нашому дослідженні педагогічні умови формування готовності міжособистісної взаємодії студентської молоді в умовах полікультурного середовища педагогічного університету ми тлумачимо як сукупність зовнішніх і внутрішніх факторів освітнього процесу, від реалізації яких залежить рівень сформованості готовності здобувачів вищої освіти до означеного процесу.

У сучасних наукових дослідженнях підготовку особистості до міжкультурної взаємодії визначають у кількох основних аспектах, а саме: 1) дидактичному, що відображає комплекс методів навчання міжкультурній взаємодії; 2) культурно-специфічному, що впливає на зміст навчання в контексті мільтикультуралізму; 3) психологічному (когнітивному, емоційному, поведінковому), що окреслюється сферою досягнення результатів (Дубасенюк, 2010).

Готовність студентської молоді до міжособистісної взаємодії в полікультурному середовищі педагогічного університету ми визначаємо як: сукупність полікультурних знань та вмінь (зокрема, уміння знаходити, оцінювати, тлумачити та використовувати на практиці інформацію полікультурного характеру, потрібної для успішної міжкультурної комунікації, дізнаватися про особливості спілкування з носіями різних культур, ураховувати в спілкуванні культурні детермінанти поведінки своїх співрозмовників, виділяти й ефективно використовувати наявний культурний контекст для забезпечення двобічної адаптації комунікативних партнерів, результативно діяти в наявних умовах комунікації); відповідні особистісні якості (шанобливість стосовно співрозмовника, толерантність до його культурних відмінностей, умов полікультурної співпраці й поведінки своїх співрозмовників, що необхідно для визначення загальних орієнтирів, ракурсу щодо розуміння різних аспектів існуючого полікультурного світу та його цілеспрямованого й усвідомленого перетворення, а також цілей комунікації та пошуку точок дотику в поглядах її учасників щодо їх досягнення); відчуття позитивних емоцій стосовно партнера по спілкуванню.

У ході наукового дослідження нами було розроблено систему педагогічних умов, які сприяють підвищенню ефективності організації процесу формування міжособистісної взаємодії студентської молоді в полікультурному середовищі педагогічного університету.

Першою умовою є організація освітнього процесу з урахуванням досвіду та цінностей студентів. Оскільки діяльність студентів детермінується соціальними нормами та наявним життєвим досвідом, перш ніж розпочати виховний вплив педагогу необхідно з'ясувати вітагенний досвід, визначити рівень засвоєних знань про гуманну поведінку, виявити ціннісні орієнтації та мотиви поведінки студентів. Актуалізація вітагенного досвіду дозволить індивідуалізувати процес виховного впливу на особистість, а також забезпечити наступність його етапів.

Інтегруючою основою будь-якої соціальної спільноти є гуманітарні 
цінності. Значення цінностей як для окремого соціуму, так і для всього людства особливо зростає на зламі епох, коли відбувається пошук нових орієнтирів розвитку. Саме тому, на думку О. Гуренко, проблема ціннісних пріоритетів сучасного полікультурного суспільства набуває особливої актуальності.

Масштабні катаклізми XX ст. супроводжувалися спалахами жорстокості, деформації гуманітарних цінностей, соціальним, моральним, економічним та інтелектуальним хаосом. Ці явища $€$ проявом культурної кризи та відбиттям глибинних станів людини. Кризові процеси відбуваються на рівні особистості та її ціннісних орієнтацій. Культурна криза є своєрідним етапом переходу культури з одного сталого стану в інший, який тільки передбачається, коли людина випадає з однієї системи цінностей і намагається ствердитися в іншій. Кожен народ (й окремий індивід) має своє уявлення про цінності та звичаї, історію, суспільні системи, культуру й релігію, та воно не завжди збігається 3 уявленнями представників інших народів і культур. Унаслідок цього інша культура, цінності тощо можуть сприйматися негативно. Віра в одну певну релігію або філософрію призводить до того, що інші системи, погляди та теорії $€$ потенційною загрозою і ставлять під сумнів правдивість чи помилковість особистих поглядів і переконань. 3 огляду на це, як вважає відома вчена, дитині ще змалечку необхідно прищеплювати національні та загальнолюдські цінності шляхом проведення відповідної виховної роботи в різних мікросоціумах (сім'ї, дитячому колективі, професійній групі тощо), створюючи належні умови для етнічної ідентифрікації юного покоління та позитивної соціалізації в нових соціокультурних умовах (Гуренко, 2014).

Найважливішими спільними цінностями громадянського виховання, що визначені фрілософією прав людини, стали: рівноцінність кожного людського життя, повага до себе та інших, свобода, солідарність, етнічна, расова, політична, культурна та релігійна толерантність, взаєморозуміння, громадянська мужність. На основі спільних цінностей радою культурного співробітництва Ради Європи розроблений Кодекс виховних цінностей, схвалений як рекомендації в умовах мультикультурного суспільства. Кодекс визначає основні ціннісні аспекти громадянського виховання, які стосуються: ставлення до себе, взаємин з іншими людьми, ставлення до суспільства, до навколишнього середовища. У ставленні до себе кодекс визнає цінність кожної особистості як унікальну сутність, яка $€$ важливою для людства сама по собі й має потенціал духовного, морального, інтелектуального та фрізичного розвитку.

У взаєминах з іншими людьми цінністю визнається ставлення до них, як таких, які вони є, а не як таких, які можуть щось зробити для нас. Такі стосунки мають важливе значення як для особистісного розвитку, так і для блага всього суспільства. Керуючись цими цінностями у людських взаєминах, необхідно поважати гідність усіх людей; давати зрозуміти іншим, що їх цінують; заслуговувати лояльність, довіру, щирість; співпрацювати 3 
іншими; підтримувати інших; поважати довіру, життя, приватність, власність інших; намагатися розв'язати проблеми мирним шляхом. У ставленні до суспільства цінується: правда, права людини, закон, справедливість і колективні зусилля для спільного блага, сім'я як джерело любові й підтримки для всіх її членів, як основа суспільства, в якому люди турбуються одне про одного (Гуренко, 2014).

Другою умовою формування готовності до міжособистісної взаємодії студентської молоді в полікультурному середовищі педагогічного університету ми визначили гуманітаризацію освітнього процесу. Гуманітарні знання $€$ основою виховання гуманістичних переконань, які знайдуть їхню реалізацію у майбутній педагогічній практиці. Студенти мають засвоїти моральні гуманістичні цінності суспільства, долучитися до багатства гуманітарної культури людства. Адже зрозуміло, що виявлення загальнокультурних компонентів у змісті освіти $є$ системоутворювальною ланкою в освітньому процесі педагогічного університету. Це сприяє розвитку в студентів таких особистісних якостей, як милосердя, альтруїзм, відповідальність, сумлінність тощо. Визначальним фактором, що впливає на виховання у студентів гуманного відношення до людини, $€$ організація освітнього процесу. Вибір форми навчальної роботи студентів (індивідуальна, парна, групова тощо) визначається наявністю навчального матеріалу та завданнями освіти. Особливої уваги маємо надавати індивідуальній формі роботи. При її виборі важливо орієнтуватися на індивідуально-психологічні особливості студентів. Індивідуальна форма навчання сприяє розвитку почуттів відповідальності, самостійності, підвищує вимогливість до себе, дозволяє самоствердитися. Ці якості забезпечують максимальний психологічний комфорт для розвитку особистості студента, який, у свою чергу, сам зможе стати генератором гуманного відношення до інших.

Акцентуємо увагу на тому, що гуманітаризацію ми розглядаємо як систему організаційних, методологічних, психологічних заходів, спрямовану на впровадження гуманістичних ідей і гуманітарних знань в освітній процес закладу вищої освіти. На наше переконання, гуманітаризація освітнього процесу має здійснюватися через зміст освіти, методи та форми навчання, гуманізацію процесу оцінювання знань студентів. Зокрема, «гуманітаризація змісту освіти передбачає інформаційне наповнення навчальних дисциплін, освітніх програм гуманітарним змістом шляхом включення у навчальновиховний процес знань про феномен «гуманного відношення до людини», його форми та прояви у суспільстві, а також залучення додаткових педагогічних, психологічних, історичних, філософських та мовних матеріалів, що допоможуть розкрити гуманістичний аспект навчальних предметів» (Зеленська, 2012).

Використання в освітньому процесі різноманітних фоорм організації навчального заняття має сприяти засвоєнню здобувачами вищої освіти гуманістичної моделі поведінки. Особливу увагу доцільно приділяти розвитку 
соціальної мотивації студентів: бажання отримувати знання, щоб бути корисним іншим людям; потреба у спілкуванні; прагнення до налагодження відношень з людьми, колективна робота; прагнення надавати допомогу і підтримку оточенню тощо. Це завдання може бути реалізоване шляхом стимулювання й заохочення гуманних міжособистісних відносин студентів; організації колективної творчої роботи, що сприятиме подальшому згуртуванню студентського колективу; застосування методів активного навчання (аналізу педагогічних ситуацій, дискусій, ділових і рольових ігор тощо).

Історичний досвід переконує, що кінцевою метою освіти у вищій школі $€$ людина, її внутрішній світ та здоров'я - духовне, інтелектуальне, фізичне. Виховувати свідому особистість в людині, пробуджувати і культивувати у ній найвищі духовні цінності та чесноти - ось що повинно бути в центрі уваги теорії і практики вищої освіти. Отже, основний ціннісний орієнтир у діяльності закладів вищої освіти - особистість студента, його людський потенціал - духовно-моральний, інтелектуально-творчий, фрізичний (Воронкова, Дебич, Дем'яненко \& Дівінська, 2014).

Нам імпонує вислів відомого фрілософра сучасності В. Андрущенка щодо гуманізації освіти: «Гуманізація вищої освіти - поняття багатовимірне. Воно охоплює зміст освіти, способи ії здобування, безпосередні й контекстуальні системні завдання їі, кінцеву мету освіти, міру доступності, можливість особи у будь-який час розпочати певний освітній цикл і припинити його, а потім знову відновити його тоді, коли їй зручно тощо» (Андрущенко, 2001, с. 16-21). Науковець наголошує, що важливими актуалітетами гуманізації вищої освіти «має стати не тільки розвиток особистості, яка здобуває освіту, а й розвиток того соціального середовища, в якому вже почала застосовувати знання зазначена особистість, або в якому вона ще тільки почне працювати після здобуття освіти» (Андрущенко, 2001, c. 16-21).

Третьою умовою формування міжособистісної взаємодії студентської молоді в полікультурному середовищі педагогічного університету $є$ гуманістична взаємодія викладачів педагогічного університету. Процес формування міжособистісної взаємодії студентської молоді в полікультурному середовищі педагогічного університету слід вибудовувати з використанням міжпредметних зв'язків суміжних курсів. На нашу думку, взаємодія викладачів із різних кафедр університету, узгодженість та об'єднання їхніх зусиль дозволить найбільш повно вирішити проблему формування міжособистісної взаємодії студентської молоді в полікультурному середовищі педагогічного університету; максимально реалізувати виховні можливості різних видів діяльності студентів; обрати оптимальні методи та форми роботи; створити особливий виховний простір, сприятливий для формування в особистості гуманістичних цінностей, своєчасного усунення недоліків та труднощі, що виникають у процесі формування міжособистісної взаємодії студентської молоді в полікультурному середовищі педагогічного університету. 
Серед основних чинників, які зумовлюють потребу в неперервній освіті науково-педагогічного працівника, вчені виокремлюють стрімке оновлення знань із сучасної педагогіки та андрагогіки, що спонукають до видозмінення традиційних форм лекційних, практичних занять зі студентами, й, відповідно, - все більшого використання форм інтерактивного, колаборативного навчання (Дем'яненко, 2019). По-друге, неформальною освітою в Україні поширюється вже набутий світовий досвід і практичні напрацювання у цій сфері. Зокрема, такі матеріали представлено на інформаційно-освітніх ресурсах «ВИЩЕ: спільнота для навчання і викладання», «PROMETHEUS» тощо.

Умотивовані викладачі мають вільний доступ до ознайомлення 3 цими матеріалами, навчатися на дистанційних курсах, відвідувати семінари тощо. Вочевидь ці та інші чинники конфліктують із традиційними поглядами на освітній процес у вищій школі як репродуктивно-ціннісний, коли навчання (у тому числі - формування ціннісних поглядів, розвиток молодіжного руху) відбувається без урахування індивідуальних потреб і запитів студента, соціального замовлення й вимог роботодавця. Адже в освіті й донині зберігається традиція орієнтуватися «на вхід» - так звану ідеальну модель студента-відмінника. Водночас найважливішою є зорієнтованість «на вихід» - модель затребуваного на ринку праці фахівця. Відповідно, кардинальні філософсько-освітні зрушення у вищій освіті пов'язані як 3 процесом викладання, так і з формуванням світоглядних цінностей у студентів. Розвиток медійних та інформаційних технологій докорінно змінює життя молодої людини. Цей процес $€$ настільки стрімким, що кардинально деформує звичний для викладача освітній процес як «лінійний», на зміну йому упроваджуються: дуальна освіта, дистанційне, змішане навчання («blended learning»), модель «перевернутого класу» («flipped classroom») тощо. 3 роками неформальна освіта користується неабияким попитом внаслідок своєї динамічності, відкритості навчання, комунікативних новацій, інформаційної мобільності й актуальності здобутих знань; тоді як в академічних освітніх програмах і планах вищої школи динаміка цих змін $€$ повільнішою (Демяненко, 2019).

$\mathrm{Ha}$ нашу думку, за умови мотивації науково-педагогічних працівників, які формують міжособистісну взаємодію здобувачів вищої освіти в умовах полікультурного середовища педагогічного університету до самоосвіти й професійного розвитку, можливе керування цим процесом в напрямі гуманістичної взаємодії, що визначено нами як третя важлива педагогічна умова формування готовності до міжособистісної взаємодії.

Висновки i перспективи подальших досліджень. Отже, обґрунтовані автором педагогічні умови, на наше переконання, дозволяють цілеспрямовано та ефективно впливати на процес формування готовності студентської молоді до міжособистісної взаємодії в полікультурному середовищі педагогічного університету, що стане підґрунтям життєдіяльності особистості у полікультурному вимірі міжнародної освіти. Перспективним 
напрямом подальших наукових пошуків стане розробка технологій професійної підготовки до формування готовності міжособистісної взаємодії студентської молоді в умовах полікультурного середовища педагогічного університету.

\section{Список використаних джерел}

Ананьев, Б.Г. (2001). Человек как предмет познания. СПб.: Питер.

Андрущенко, В. (2001). Основні тенденції розвитку вищої освіти України на рубежі століть (Спроба прогностичного аналізу). Вища освіта України.

Бодалев, А.А. (1993). Психология межличностных отношений. Вопросы психологии, 2, $86-91$.

Бронська, А. (2000). Лінгвокраїнознавчий аспект у викладанні української мови як іноземної. Дивослово, 7, 43 - 44.

Будій, Н. (2008). Формування лінгвокреативних здібностей в учнів початкової школи. Психолого-педагогічні проблеми сільської школи, 27, 50-55. URL: http://nbuv.gov.ua/UJRN/Ppps_2008_27_10

Булах, І. (2005). Викладач-студент: психологія міжособистісних взаємодій: навч.-метод. посіб. Національний педагогічний ун-т ім. М. П. Драгоманова. Київ.

Васютинський, В.О. (2010). Психологічні виміри спільноти: монографія. НАПН України, Ін-т соц. та політ. психології. К.: Золоті ворота.

Воронкова, Б.А., Дебич, М.А., Дем'яненко, Н.М., \& Дівінська, Н.О. (2014). Оптимізація циклу соціально-гуманітарних дисциплін у вищій освіті України в контексті євроінтеграції: монографія (рукопис). Онкович, Г.В. (Ред). Київ.

Гуренко, О.І. (2014). Соціально-педагогічна робота в полікультурному суспільстві: навч. посібн. для студ. ВНЗ. Баханов, К.О. (Ред.). Донецьк: Ландон-XXI.

Демяненко, О.О. (2019) Активні фрорми взаємодії викладача і студентів у навчально-виховному процесі вищої школи: організаційнометодичні аспекти: навчально-методичний посібник. Біла Церква.

Дубасенюк, О.А., Якса Н.В. (2010). Проблема полікультурної підготовки студентів у зарубіжній педагогічній науці і практиці. Профресійна освіта: педагогіка і психологія: Польсько-український, українопольський щорічник. Левовицький, Т., Вільш, І., Зязюн, І., Ничкало, Н. (Ред.). Ченстохова-Київ.

Жернов, В.И. (1999). Теоретико-методологические основы формирования профессионально-педагогической направленности личности студента педагогического вуза. Магнитогорск: Магнитогорский гос. пед. ин-т.

Зверева, М.В. (1987). О понятии «дидактические условия». Новые исследования в педагогических науках. В.С. Самойлова (Ред.). М.: Педагогика. 
Зеленська, О.М. (2012). Формування полікультурної компетентності курсантів вищих військових навчальних закладів у процесі вивчення гуманітарних дисциплін. Дис. канд. пед. наук. Харків.

Ломов, Б.Ф. (2002) Общение: понятие, формы. Психологический журнал, 6 , $26-27$.

Філософрія інтеграції: монографія. Бондаренко, В.Д., Ващук, Ф.Г. (Ред.). Ужгород: ЗакДУ, 2011.

\section{References (translated and transliterated)}

Anan'yev, B.G. (2001). Chelovek kak predmet poznaniya [Man as a subject of knowledge]. SPb.: Piter. [in Russian].

Andrushchenko, V. (2001). Osnovni tendenciï rozvitku vishchoï osviti Ukraïni na rubezhi stolit' (Sproba prognostichnogo analizu) [The main trends in the development of higher education in Ukraine at the turn of the century (An attempt at prognostic analysis)]. Vishcha osvita Ukraïni - Higher education in Ukraine. [in Ukrainian].

Bodalev, A.A. (1993). Psikhologiya mezhlichnostnykh otnosheniy [Psychology of interpersonal relationships]. Voprosy psihologii - Psychology issues, 2, 86 - 91. [in Russian].

Brons'ka, A. (2000). Lingvokraïnoznavchij aspekt u vikladanni ukraïns'koï movi yak inozemnoï [Linguistic aspect in teaching Ukrainian as a foreign language]. Divoslovo, 7, 43 - 44. [in Ukrainian].

Budij, N. (2008). Formuvannya lingvokreativnih zdibnostej $v$ uchniv pochatkovoï shkoli [Formation of linguo-creative abilities in primary school students]. Psihologo-pedagogichni problemi sil's'koï shkoli - Psychological and pedagogical problems of rural school, 27, 50-55. URL: http://nbuv.gov.ua/UJRN/Ppps_2008_27_10 [in Ukrainian].

Bulah, I. (2005). Vykladach-student: psykholohiya mizhosobystisnykh vzayemodiy [Teacher-student: psychology of interpersonal interactions]: navch.-metod. posib. Natsional'nyy pedahohichnyy un-t im. M.P. Drahomanova. Kïiv. [in Ukrainian].

Vasyutins'kij, V.O. (2010). Psykholohichni vymiry spil'noty [Psychological dimensions of community]: monohrafiya. NAPN Ukrayiny, In-t sots. ta polit. psykholohiyi. K.: Zoloti vorota. [in Ukrainian].

Voronkova, B.A., Debich, M.A., Dem'yanenko, N.M., \& Divins'ka, N.O. (2014). Optymizatsiya tsyklu sotsial'no-humanitarnykh dystsyplin u vyshchiy osviti Ukrayiny $v$ konteksti yevrointehratsiyi [Optimization of the cycle of social sciences and humanities in higher education in Ukraine in the context of European integration]: monohrafiya (rukopys). Onkovich, G.V. (Ed.). K. [in Ukrainian].

Gurenko, O.I. (2014). Sotsial'no-pedahohichna robota v polikul'turnomu suspil'stvi [Socio-pedagogical work in a multicultural society]: navch. posibn. dlya stud. VNZ. Bahanov, K.O. (Ed.). Donec'k : Landon-HKHI. [in Ukrainian].

Demyanenko, O.O. (2019) Aktyvni formy vzayemodiyi vykladacha i studentiv u navchal'no-vykhovnomu protsesi vyshchoyi shkoly: orhanizatsiynometodychni aspekty [Active forms of interaction between teacher and 
students in the educational process of higher school: organizational and methodological aspects]: navchal'no-metodychnyy posibnyk. Bila Tserkva. [in Ukrainian].

Dubasenyuk, O.A., Yaksa, N.V. (2010). Problema polikul'turnoyi pidhotovky studentiv u zarubizhniy pedahohichniy nautsi i praktytsi [The problem of multicultural training of students in foreign pedagogical science and practice]. Profesijna osvita: pedagogika i psihologiya - Vocational education: pedagogy and psychology. Pol's'ko-ukraïns'kij, ukraïno-pol's'kij shchorichnik. Levovic'kij, T., Vil'sh, I., Zyazyun, I., Nichkalo, N. (Ed.). Chenstohova-Kiïv. [in Ukrainian].

Zhernov, V.I. (1999). Teoretiko-metodologicheskiye osnovy formirovaniya professional'no-pedagogicheskoy napravlennosti lichnosti studenta pedagogicheskogo vuza [Theoretical and methodological foundations of the formation of the professional and pedagogical orientation of the personality of a student of a pedagogical university]. Magnitogorsk: Magnitogorskij gos. ped. in-tut. [in Russian].

Zvereva, M.V. (1987). O ponyatii «didakticheskiye usloviya» [About the concept of "didactic conditions»] Novye issledovaniya $v$ pedagogicheskih naukah. Samojlova, V.S. (Ed.). M.: Pedagogika - Pedagogy. [in Russian].

Zelens'ka, O.M. (2012). Formuvannya polikul'turnoyi kompetentnosti kursantiv vyshchykh viys'kovykh navchal'nykh zakladiv u protsesi vyvchennya humanitarnykh dystsyplin [Formation of multicultural competence of cadets of higher military educational institutions in the process of studying humanities]. Candidate's thesis. Harkiv. [in Ukrainian].

Lomov, B.F. (2002) Obshchenie: ponyatie, formy. Psihologicheskij zhurnal Psychological journal, 6, $26-27$. [in Russian].

Filosofiya intehratsiyi [Philosophy of integration]: monografiya. Bondarenko, V.D., Vashchuk, F.G. (Ed.). Uzhgorod: ZakDU, 2011. [in Ukrainian].

УДК 378.046.4: 373.58/.5.091.2.011.3-051:51]:004

DOI: https://doi.org/10.35387/od.2(18).2020.97-105

Мар'єнко Майя Володимирівна - кандидат педагогічних наук, старший науковий співробітник відділу хмаро орієнтованих систем інформатизації освіти Інституту інфоормаційних технологій $і$ засобів навчання НАПН України

ORCID iD: https://orcid.org/0000-0002-8087-962X

E-mail:popelmaya@gmail.com

\section{КОМПЕТЕНТНОСТІ ВІДКРИТОЇ НАУКИ ВЧИТЕЛІВ ПРИРОДНИЧО-МАТЕМАТИЧНИХ ДИСЦИПЛІН}

Анотація. В оглядовій статті розглянуто компетентності відкритої науки в широкому значенні та як складник профресійної компетентності вчителя природничо-математичних предметів для 